\title{
SELECTIVE AND "VEILED" DEMARKETING FROM THE PERSPECTIVE OF BLACK FEMALE CONSUMERS
}

\author{
Demarketing seletivo e "velado" na visão de consumidoras negras
}

Ana Raquel Coelho Rocha*

Leticia Moreira Casotti* ${ }^{\star *}$

\begin{abstract}
This study sheds light on the perspective of Black female consumers in regard to certain effects of marketing initiatives adopting the literature on demarketing as a framework. The context examined is their experience with the market of hair beauty and care. Media actions are analyzed along with narrative interviews in order to understand the phenomenon. The findings reveal a dominant structural pattern which perpetuates the marginalized status of Black women's natural traits. Emerging market initiatives point to movements concerning the visibility of these female consumers, who despite being eager to consume, have their demand discouraged. This suggests that they perceive selective and veiled demarketing as one of the results of marketing actions. The analysis invites for theoretical reflections on demarketing and veiled racism in Brazil.
\end{abstract}

Keywords: Demarketing. Veiled Racism. Consumption. Hair. Black Women.

\section{RESUMO}

Este trabalho traz a visão da consumidora negra sobre efeitos de ações de marketing, apoiando-se na literatura sobre demarketing. 0 contexto investigado é sua experiência no mercado de tratamento e beleza dos cabelos. Informações originadas de diferentes manifestações midiáticas se somam às entrevistas narrativas para a interpretação do fenômeno. Os achados revelam um padrão estrutural dominante, que perpetua a condição marginal dos traços naturais dessas mulheres; aspectos emergentes do mercado, que apontam movimentos rumo à visibilidade dessa consumidora, e que essas mulheres se mostram ávidas por consumir, mas se sentem desencorajadas em sua demanda. Isso sugere que percebem o demarketing seletivo e velado, como um dos efeitos das ações de marketing. A análise dá origem a reflexões teóricas sobre demarketing e racismo velado no Brasil.

Palavras-chave: Demarketing. Racismo Velado. Consumo. Cabelo. Mulher Negra.

\footnotetext{
* Doutora em Administração pela Pontifícia Universidade Católica do Rio de Janeiro (PUC-Rio). Pós-Doutora em Administração pelo Instituto Coppead de Administração da Universidade Federal do Rio de Janeiro (UFRJ). E-mail: anaraquel.rocha@coppead.ufrj.br. ORCID: 0000-0002-0478-5146

** Professora Associada do Instituto Coppead de Pós-Graduação e Pesquisa em Administração da Universidade Federal do Rio de Janeiro (UFRJ) e Coordenadora do Centro de Estudos em Consumo Coppead da Universidade Federal do Rio de Janeiro (UFRJ). Doutora em Engenharia de Produção pela Universidade Federal do Rio de Janeiro (UFRJ). E-mail: leticia@copopead.ufrj.br. ORCID: 0000-0001-7718-5072
} 


\section{INTRODUCTION}

$\mathrm{B}$ lack Brazilians experience unequal relations in several areas of social life (IPEA, 2013) and consumption is one of them (MARTINS, 2015; TELLA, 2006). Market research has paid little attention to the consumer behavior of Black people, despite their obvious presence in consumption spaces. Within the corporate environment a "White logic" prevails and seems to control both the decisions on products and services offers, and the positioning of such offers in mass or specialized media (ROCHA; CASOTTI, 2017). As pointed out by Lázaro Ramos in his autobiography (RAMOS, 2017, p. 126), "[...] the world today revolves around the rules of the market and Black children that don't learn how to deal with these rules will achieve little to nothing in life".

The focus of the present study is on the experience of Black female consumers with offerings of hair beauty and care products and services. Available data sustain the continued importance of this industry in the country, even in a scenario of economic recession (ABIHPEC, 2015). "How do Black female consumers perceive current marketing actions related to the offerings of hair beauty and care products and services?" This question stimulated our reflections concerning a group of consumers that has started to broadly manifest their dissatisfactions with the market and to expose the racism experienced in the quotidian life (ZAMORA, 2012). In order to investigate how Black female consumers perceive current marketing actions within the hygiene and beauty markets, we have followed social media posts, virtual groups, blogs, YouTube videos and other media initiatives related to the topic for two years. The data was analyzed along with the in-depth narratives obtained from fifteen interviews with Black women concerning hair care.

The concept of demarketing was selected to support the research findings due to the nature of Black female consumers' experiences in the marketplace. Demarketing is a concept that departs from the perspective of corporations and deals with "[...] discouraging customers in general or a certain class of customers in particular on either a temporary or permanent basis" (KOTLER; LEVY, 1971, p. 75). A significant part of products and services available in the market does not explicitly target Black consumers (BARBOSA, 2004; MARTINS, 2015), which characterizes the group's demand as latent (KOTLER, 1973; LENGLER; VIEIRA; FACHIN, 2002). Their modest presence in the media also suggests that they are not a relevant target audience for the services and products being offered (GROSS, 2014; MARTINS, 2015). Lengler et al. (2002, p. 89) reinforce the idea of latent demand and selective demarketing when they point to vastly adopted market segmentation practices permeated with discrimination, resulting from social and historical relations based on the secondary and submissive role of Black people, while the White population enjoys a dominant and oppressive status.

How do Black female consumers experience the market of hair care? It was possible to identify a number of studies correlating the hair with the construction of female identity (HARRISON et al. 2015; BOUZON, 2008; McCRACKEN, 1995). Other works describe the experiences of Black women with their hair (THOMPSON, 2009; NDICHU; UPADHYAYA, 2018). Yet, no studies could be found when it comes to examining how Black female consumers see (or don't see) the management of marketing offers or questioning if they feel any kind of discouragement vis-à-vis product and service offerings. 
This study reverses the conventional perspective on the concept of demarketing, which focuses on the actions of enterprises, by contemplating the consumers' perception regarding the management of marketing practices, more specifically the consumers' point of view concerning the practice of demarketing by companies. The literature on demarketing is comprised by essays (CULLWICK, 1975; GERSTNER, HESS; CHU, 1993; KOTLER, 2011; KOTLER; LEVY, 1971), and a number of research studies (BEETON, 2003; GRINSTEIN; NISAN, 2009; GROFF, 1998; GUNDLACH; BRADFORD; WILKIE, 2010; KARYY; TRACH, 2014; LEE; CUTLER; BURNS, 2005; MCGRATH, 2008; MARK; BRENNAN, 1995; MIKLOS-THAL; TODA, 2006; WHITE; THOMAS 2016), albeit always from the perspective of the companies.

This inversion of focus raises new issues, reflections and debates in the field of marketing management, since the nature of marketing activities is the creation of demand, not its destruction (GERSTNER; HESS; CHU, 1993). Understanding Black female consumers' discouragement experiences becomes relevant given that consumption is also a means to resignify cultural representations associated with social discrimination, racism, and stigma (GOFFMAN, 1963; LAMONT; MOLNÁR, 2001; OLIVEIRA, 2011; TELLA, 2006; SANDIKCl; GER, 2010; ZAMORA, 2012).

In the present paper we intend to instigate researchers and marketing professionals to reflect on the "invisible" (BARBOSA, 2004) or "undesirable" status of Black consumers, terms taken from the literature on selective demarketing (KOTLER, 1973). In sequence, we present studies that examine how Black consumers' invisibility manifests itself. The following sections describe the research steps, analyze the findings, and present a final discussion covering the main reflections and contributions of this study.

\section{THE DISCOURAGED CONSUMER: DEMARKEING}

The concept of demarketing was proposed by Kotler and Levy (1971) to analyze a marketing strategy that instead of conquering new consumers, wishes to discourage them. The authors discuss demarketing intension to "creatively" handle excessive demand, discouraging consumption by general consumers, or just by a specific set or group, limiting their access to products or services. This discouragement practice may be permanent or temporary. The practice of demarketing was originally conceived within a context of abundance (CULLWICK, 1975). Limitations resulting from moments of shortness led companies to adopt marketing strategies that would reduce the demand (CULLWICK, 1975; GROFF, 1998).

Kotler and Levy (1971) present three types of demarketing. The first, "general demarketing", is adopted in the case that the company wishes to reduce the overall level of demand. The second, "ostensive demarketing", is a resource used when companies just want to give the impression of demand discouragement, although aiming at the opposite: a demand increase. The last, "selective demarketing", is an option for companies wanting to discourage the demand by a certain segment or group of consumers. Gerstner, Hess and Chu (1993) list some demarketing strategies: i) demarketing through "price discriminating" which intends to control the demand, giving discounts at specific times of the day, for example; ii) "bait and switch" demarketing - a questionable and possibly illegal practice - is adopted 
to discourage customers from buying certain brands, while channeling the demand to more lucrative ones; iii) "stock outage" demarketing means completing sales, though guaranteeing product delivery at a future date; and iv) "crowding costs" demarketing, when an enterprise charges higher prices in order to control limited offerings, thus avoiding overcrowd and consumer lines.

The authors add "differentiation demarketing", a strategy used by companies to control demand, differentiating their offers from the competition. Gerstner, Hess and Chu (1993) mention that firms may create a "nuisance factor", such as low stock levels, in order to establish a differentiation from well-established competitors. The authors highlight that companies selling the same product, without differentiation demarketing, would be subjected to eventual price wars, negatively affecting their profits. The use of the "nuisance factor" by a company practicing low prices would shift part of the demand to a well-established competitor. As a consequence, the latter could increase their prices due to the higher demand. The benefit for the business originally adopting the "nuisance factor" is the possibility for a future price increase, following the competition, though continuing to satisfy the needs of customers that tolerate such annoyance. According to Gerstner, Hess and Chu (1993), both companies benefit from such segmentation strategy as they are then able to practice prices above the costs.

Whatever strategy is adopted, it is possible to infer that the demarketing strategy described by Gerstner, Hess and Chu (1993) has been used as a counterpoint - or as consequence of - marketing actions targeting customers that theoretically receive regular offers. In the case of Black consumers, few are the offers explicitly directed to them, suggesting that in regard to some product categories their demands are modestly satisfied (MARTINS, 2015; ROCHA; SCHOTT; CASOTTI, 2016). In other words, while segmenting their markets, and with disregard to the existing economic inequalities between racial groups in Brazil, companies end up adopting criteria that place Black people at the margins in terms of consumption relations (LENGLER et al., 2002).

Kotler's (1973) seminal work defines eight demand states related to marketing management tasks. For a demand classified as negative, disapproving or avoiding certain offers, the author suggests marketing efforts to convert it into a positive one. "No demand" is a state that points to indifference or lack of interest towards the offerings. In this case, the author recommends marketing professionals to look for connections between the offer and some existing need, or to attempt to change environmental aspects to add value to the offer. Faltering demand is defined as a situation when the demand is lower than usual, and at risk of a greater decline, and therefore the objective should be to revitalize the life cycle of declining products. Demand fluctuations fits into what Kotler classifies as irregular demand, requiring actions that synchronize offer and demand, e.g., the adoption of lower prices during low season. In cases of full demand, market and demand are aligned in terms of timing and desired level, and it becomes the marketing manager's responsibility to sustain such demand state. When demand level surpasses the market supplying capacity, a state of overfull demand occurs, and demarketing actions are suggested in order to reduce the demand. Unwholesome demand is a state in which demand is always considered excessive once it is associated with products which have undesirable qualities (e.g. alcohol and drugs). A state of latent demand is characterized by consumers' interest in inexistent or more adequate products vis-à-vis market offers. In this situation, the recommendation is the coordination of 
marketing efforts towards market development and the conversion of the latent demand in actual demand. This last demand state seems to be closer to the situation of Black female consumers, who are eager to acquire proper services and products (LAMONT; MOLNAR, 2001; LENGLER et al., 2002).

Since the concept of demarketing emerged (KOTLER; LEVY, 1971), the literature has expanded. There are research studies dealing with the practice of demarketing related to tourism (GROFF, 1998; BEETON, 2003); to health care (LEE; CUTLER; BURNS, 2005; MARK; BRENNAN, 1995; WHITE; THOMAS, 2016); to natural resources (GRINSTEIN; NISAN, 2009; MCGRATH, 2008; KARYY; TRACH, 2014; KOTLER, 2011); to products deviated from legal sources to illegal consumption (GUNDLACH; BRADFORD; WILKIE, 2010); and to the quality perception of certain offers (MIKLOS-THAL; ZHANG, 2013). It was possible to notice a common trait in these works: a degree of moral judgement that leads to a positive social attitude towards demarketing. This means that the use of the strategy is commonly related to practices associated with people's well-being or the preservation of non-human assets, such as the environment.

In the Brazilian context, the recent study by Toda (2016) follows a different path. The author makes use of the demarketing concept to approach strategies adopted by companies to handle undesirable customers, such as those perceived by service providers as having "bad manners". In this case, customers are not previously discouraged to consume, but rather become unwelcomed due to the behavior displayed in interpersonal relations taking place along the consumption process. Research in which demarketing practices may receive a negative social judgement, for example, when certain customers are previously segregated, i.e., are discouraged to consume, could receive more attention.

\section{THE CONSUMERS WITH “NO COLOR”? CONSUMPTION INVISIBILITY}

In recent years, Black people have achieved a new consumer status in Brazil and have started to occupy new consumption spaces (IBGE, 2014). Yet, this group remains "invisible" (BARBOSA, 2004), being subjected to the "White logics" in the marketplace (ROCHA; CASOTTI, 2017), i.e. one that favors the non-Black population and disregards race issues in great part of the offers and communication about products and services (GRIJÓ; SOUZA, 2012; MARTINS, 2015). It is as if offers targeting White consumers could, for instance, reach Black people in their motivations (BAUER; CUNNINGHAM; WORTZEL, 1965; BULLOCK, 1961; TELLA, 2006).

Advertising is one of the most common tools employed in Marketing when communicating offers. The study by Martins (2015, p. 43) helps to understand the development of myths related to the generalization of offers that initially targeted non-Black consumers. The author retrieves statements made by advertisers in regard to Black consumers some decades ago. One of them asserted that Blacks covet White people's possessions, a rationale for the use of White models in advertising campaigns targeting the general audience. Another statement assumed that Blacks are underprivileged in order to justify their little presence in advertising and reinforce the belief that depicting White people means representing the majority, the stereotypical consumer. 
Another professional cited by Martins (2015, p. 43) explains that Blacks are not depicted in advertising because people want to be represented as rich, beautiful and powerful, attributes associated with the White population. Martins adds an old quote from an advertiser that clearly exemplifies the exclusion and invisibility of Black people in promotional pieces: consumers have no color, but they are not Black. Although Martins (2015) refers to the past, these statements seem to remain contemporary given that, in the author's opinion, advertising has not yet made a substantial progress in the depiction of Black people, a conclusion shared by other authors (GRIJÓ, 2014; GRIJÓ; SOUZA, 2012).

Television is regarded as a crucial mass communication vehicle in Brazil (ARAÚJO, 2008). GEMAA (Grupo de Estudos Multidisciplinares de Ações Afirmativas/Multidisciplinary Group of Affirmative Action Studies) (2015) has conducted a study to survey the number of soap operas' (telenovelas) Black protagonists between 1994 and 2014. Only 4\% of the main roles were performed by Black actresses. Vascouto (2016) listed the racist stereotypes that Brazilian soap operas should abandon, such as the "sassy, subservient, gossiper, seductive and submissive" maid. In the book (ARAÚJO, 2000) and documentary A negação do Brasil - O Negro nas Telenovelas Brasileiras (2000), Araújo also explores the influence of soap operas in the process of construction—or "lack of construction" - of a Black identity. Black actor Lázaro Ramos (2017) claims that changes in the media are signs of changes in the society and considers that the protagonist roles he has performed constitute exceptions. Ramos reminds us that exceptions ratify rules, and he adds that racism inhibits people from following their path and prejudice may end up dictating their actions (RAMOS, 2017, p. 102).

Aside from issues related to the ways and the amount of Black people exposure in mass media, there are peculiarities in the Brazilian context that reinforce the invisibility condition of the Black population as consumers. First, there is some indifference towards the effects of social inequalities, which mainly affect Black citizens (CARNEIRO, 2002). Also, while the existence of racism in the country is denied (MIRANDA-RIBEIRO, 2006), veiled racism behind an appearance of social acceptance is common (DA MATTA, 1986; LEITÃO, 2015). Issues related to racial differences remain relatively unknown and are not sufficiently debated among Brazilians (FREYRE, 1986; GOMES, 2003). Few Brazilians have heard in or out of school that one of the purposes of the early $20^{\text {th }}$ century White immigration wave intended to "whiten" the local African descent population (DOMINGUES, 2002).

Part of the Brazilian society still sustains the myth of racial democracy (ZAMORA, 2012), but Blacks live a reality of stigma (GOFFMAN, 1963; TELLA, 2006) and racism (ZAMORA, 2012). The topic is not clearly dealt with in the country, though Black consumers' characteristics seem to be socially understood as a defect or disadvantage (GOFFMAN, 1963). Race theories, both older and recent, point to physical traits to explain racism (APPIAH, 1997, p. 30). Appiah (1997) presents a painful realization that meanings and practices were built in such a way that distinct aesthetics would be mistakenly understood as moral distinctions, with Blacks being subjected to an inferior position, both in regard to their appearance and their morals.

The consumption sphere contradicts the myth of racial democracy and unveils the existing racism within the market of goods and services (TELLA, 2006). Black people often experience public sanctions and discrimination in consumption situations (BENNETT et al., 
2014; CROCKER; MAJOR; STEELE, 1998; LINK; PHELAN, 2001), and they have to create ways to deal with the issue (TELLA, 2006). Social media emerge as a means to disclose the discrimination and racism experienced by Black consumers, while serving as a space to expose the existing painful prejudice, such as the one surrounding Black women's hair. The natural afro-textured hair is a target for negative representations -"bad", "coarse", in need of "taming" (BOUZON, 2008 p. 245). Identity is expressed, displayed and revealed by the physical body which is subjected to myths, representations, and distinct consumptions.

A number of research studies have been dedicated to understanding consumption practices and identity construction (e.g. BELK, 1988; LUNT; LIVINGSTONE, 1992; SLATER, 1997; TOMLINSON, 2006; WARDE, 1994). Belk (1988) emphasizes how people subjectively perceive who they are and how identity construction is a continuous process permeated with conflict. Holt and Thompson (2004) describe identity formation as a malleable process, constructed through codes, practices, and performances, where consumers deal with contradictions and identity difficulties posed by the marketplace in their search for a coherent self. Arnould and Thompson (2005) describe the market as a source of myths related to identities, in which a simultaneous process of identification and differentiation from others takes place.

Some studies cover the difficulties caused by market structures in the construction of coherent and dignified identities (ARVIDDSON, 2005; HOLT, 2002), and the challenges for the achievement of utopian ideals created by the market (KOZINETS, 2002; BELK; GER; ASKEGAARD, 2003). Firat and Venkatesh (1995) describe an "empty self" or a "decentralized self" that results from identity games played within the market. Fordham (1996) analyzed the identity dilemmas faced by Black youngsters. The author brings the expression "act like a White person" that refers to a standardized ethics imposed by White hegemony and that may lead to a deconstruction of the Black identity still in search for their affirmation. Breakwell (1986) tackles identity construction departing from some characteristics such as continuity, distinction, agency, control, and self-esteem. Giddens (1991) highlights the social interactions that comprise this continuous process. Those characteristics may constitute a challenge for Black female consumers facing a marketplace dominated by Eurocentric representations. These representations have historically (and socially) discriminated Black aesthetics, contributing to their invisibility. It is noticeable that companies in the hygiene and beauty sector direct their offers favoring culturally hegemonic White identity, in a social context that judges and disapproves people based on physical attributes (HALL, 1993). The hair may act as a tool to classify, hierarchize, qualify, disqualify, exclude and include people (BOUZON, 2008 p. 232); and for Black women, this touches identity issues that are even more specific and sensitive (THOMPSON, 2009; NDICHU; UPADHYAYA, 2018).

\section{METHODOLOGY}

This study adopts an interpretive approach (ARNOULD; THOMPSON, 2005) and qualitative methods to capture the consumer perspective on the phenomenon, through primary and secondary data (REMENYI et al., 1998).

The work examines how Black female consumers understand current marketing actions. We depart from the assumption that Blacks are overlooked by the market in regard 
to the development and communication of offers, and experience a kind of discouragement in the consumption of services and goods. The context of analysis is the experience of Black women as consumers of products and services for hair beauty and care.

Narrative interviews (MILES; HUBERMAN; SALDANA, 2013) with 22 women were conducted. From this group, which is part of a larger study, 15 interviewees were selected. Their accounts were more specific in relation to market experiences, suggesting a discouragement in the consumption of hair beauty and care products and services. Rio de Janeiro city residents, participants were women between 28 and 57 years old, with varied hairstyles (natural, straightened, braided, dreadlocked, among others).

In the beginning, there was some curiosity regarding a better understanding of the affluent Black female consumer behavior given that Blacks are often associated with lower income groups (OLIVEIRA; VIEIRA, 2009). Family income was abandoned as the main criteria for participants' selection when early accounts suggested that there were no differences in the ways women of distinct social strata were affected by marketing actions applied in the market of hair products and services.

According to Pedrosa and Schwarcz (2014), in Brazil different skin color tones are observed when people are asked to self-declare. Selected participants self-declared as Black women. In some cases, self-declaration occurred after the guideline initial questions were asked. The final group was comprised of women who self-declare as Black and belong to different strata within the Brazilian socioeconomic pyramid. Interviews were an hour-long on average and were conducted in places chosen by the respondents, e.g., home, workplace or coffee shops. The accounts were recorded and transcribed, resulting in approximately 320 pages of material for analysis.

Aside from the consumers' interview narratives, a two-year systematic recording of manifestations related to the Black community media was carried out, contributing to the interpretation of the phenomenon. We followed 105 links, including social media (Facebook and Instagram), YouTube, websites, and blogs. The links were analyzed and associated with five preliminary categories. The first covers aesthetic standards, racism and activism (62 links), topics more closely related to the main research focus. Market offers are the second category and 22 links within the scope of this article were found. Other categories complemented the study: social movements progress ( 8 links); pages specialized in Black beauty ( 7 links); and history of the Black people ( 6 links).

If, on the one hand, the almost exclusive use of Facebook for the data collection could imply some limitation; on the other hand, it allowed a greater proximity of the researchers with current and widely discussed topics in Brazil. We followed the Facebook group Cacheadas em Transição (OFICIAL) ("Curly in Transition - Official") for 6 months. This is a space that offers support for Black women throughout transitioning stages, from straightened hair to natural texture. The group was chosen due to the significant number of members, close to 278 thousand at the time of data collection completion. In our search for Facebook pages that deal with hair transition, the word "transition" was used as the keyword.

The narrative interviews, the collected posts, the information gathered on the media, blogs and websites were analyzed conjointly. Sometimes information coming from different sources were supportive, i.e., similarities and convergence were detected. In other 
situations, they were complementary, adding details not found in another source. Information collected in the media help us understand the markets and the diverse existing (or non-existing) connections between the offers and the demand, as well as the complexity of this context.

Fieldwork findings were analyzed following Bardin's (2006) content analysis guidelines. At the data pre-analysis stage it was possible to identify the most relevant information for the study. In sequence, the selected material was examined in order to establish categories consonant with the research question and the adopted theoretical framework. As initially planned, data was processed using Atlas.ti as reading and rereading narratives was sufficient for inference, interpretation and critical verification, as recommended by Bardin (2006). Data was analyzed and, along with the interviews' accounts, led to identification of three categories (BARDIN, 2006). Categories that emerged are described and analyzed in sequence.

\section{MAIN FINDINGS}

The identified analysis categories show three facets of the consumption discouragement experienced by Black female consumers. The first reveals a prevailing structural pattern that points to a perpetuation of the marginal status of Black women natural traits. The second part of the analysis presents emerging market aspects which suggest paths and movements towards a greater visibility of Black female consumers who are returning to their natural hair texture and facing racism. The last category shows women who are eager to consume, but who seem to have their demand discouraged, pointing to a perception of selective and veiled demarketing behind the current marketing actions.

\section{AVOIDING NATURAL HAIR AND ACCEPTING THE STANDARD}

The condition of "invisibility" through hair starts in childhood, when consumers are exposed to a beauty standard to be followed - "the White standard" - without being introduced to alternative aesthetic styles. Straightening their natural hair is a practice that would, to a certain degree, get these Black female consumers closer to the socially accepted hairstyle. (see BOUZÓN, 2008). When adopting this style, part of the consumer's ethnic background "would disappear". Magda (45 years old), for example, has lived in Denmark for more than ten years, but still holds the memories of her experiences as a child and adolescent in Brazil: "where the beauty standard is the White standard". Today Magda wears wavy hair extensions.

Interviewees are conscious that, in Brazil, Eurocentric beauty standards are valued, something quite distant from their natural looks. Vilma (44 years old) remembers feeling as "the ugly duckling in childhood". In her account, she also suggests that erasing her racial identity seemed to be the norm, and certain discomfort could be experienced when she didn't subject to the standard: 
My parents never explored the possibility that I would need to accept myself as a Black woman, with kinky hair. They never told me so. I thought I was ugly, that my hair was horrible, it wouldn't grow, I hated it, I hated everything about myself.

Today Vilma keeps her hair with the natural texture and has abandoned the use of chemicals. For some interviewees, straightening their hair seems to be a solution for making them somewhat "visible". In specific contexts, straight hair makes them feel closer to the imaginary, which is sometimes associated with their White peers who are socially "visible". In her interview, Maria reported that "since a kid she always wanted to have straight hair". The school environment was important for the construction of her perception regarding the hairstyle to be adopted. The interviewee described her choice for straight hair as an element of belonging to a certain group, of higher socioeconomic status, and closer to the Eurocentric standard:

I studied in a school where most students were middle class, so there were richer people, of a higher social class. A great part [of the female students] had straight hair and I thought their hair was beautiful, and I didn't want to wear curly hair; firstly because nobody did, every person of color like me, or even Whites, who had curly hair used to straighten it, so I didn't want to feel different from the group.

Later, in adulthood, Maria's "straight" hair would increase her chances of acceptance and reduce social disapproval in other spheres of life. The interviewee narrates her perception regarding the proper hairstyle for a corporate environment (a topic pointed out by PIRES; MOCELLIN, 2016). Such social adjustment is reported by the participant as something she believes to be common sense. It is as if not only her look, but the look of the "Other", would lead her to an interpretation regarding straightened hair, which helps to understand the context in which she lives and some related outcomes. An excerpt from the interview clarifies the point: "It's not just the hair, there is the whole context. Today if you straighten your hair and put on a women's suit, you look like a business woman [...] when [the person] gets to an interview, she's going to be rejected because of her [curly] hair". Along with Maria, other interviewees pointed to the natural afro-textured hair as the least acceptable in corporate environments.

The natural texture of Black hair is viewed by some interviewees as a "problem" with which they must deal along their lives. Part of the explanation may come from the maternal look when they were still children or adolescents; or the masculine look at the hair as an aesthetic attribute in the adult life. Some accounts detail how mothers used to impose that natural hair needed to be "tamed". One participant of the group Cacheadas em Transição (OFICIAL) reported her husband's initial objection to her decision of abandoning hair straightening.

We found a highly critical article from a famous band with no Black members in a magazine targeting teenagers (RIBEIRO, 2015). One of the band members, when giving his opinion on braided hair, suggests that "for those who have bad hair [natural afro-textured hair]", wearing braids meant a kind of "salvation". According to the article, "their racist 
response was followed by laughter from the three [band] members". Respecting the natural hair and avoiding chemicals becomes a gesture of resistance in a context that imposes a specific standard. According to a number of interviewees, the adoption of natural hair by a Black woman is something that requires courage. Marilda (51 years old) explains that a woman who chooses the natural afro-textured hair

[...] is a woman with courage, because it's too difficult, people pressure you, because everyone wants you to flat iron, to straighten your hair; everyone thinks it's ugly, a lot of people confuse this kind of hair with being sloppy, lacking care.

\section{RESPECTING THE NATURAL BLACK HAIR TEXTURE AND CONFRONTING RACISM}

Black Brazilian women are in search of visibility in several social spheres. The internet has become a platform for portraying Black women in a new and more proud social status in relation to aesthetics and beauty. Movements of collective support to face the difficult transitioning from hair straightening to natural texture are an example of the new possibilities brought up by digital media, where opinions and protests get widespread very quickly. At the same time, this exposure opens up a space for racist comments and attitudes, such as offensive words and aggressive manifestations against Black aesthetics, having Black actresses as a target, for example, attitudes that were denounced and openly covered by the media (G1, 2015). In web search pages one can identify Black women rebuking racist practices in general (RIBEIRO, 2016).

To these examples, we can add Facebook pages directed to issues that have currently mobilized Black women (Pipa Azul, Pretas Simoa, Cacheadas em Transição e Geledés - Instituto da Mulher Negra, among others). Martins (2015) notes the representation (or under-representation) of Blacks in advertising. It is on the internet that different debates regarding image are arising and are helping to forge a "new" Black female consumer identity.

Black Brazilian women are depicted occupying new spaces of recognition. Beauty is a theme of paramount importance in Brazil and it remains privileging women with features closer to the Eurocentric standards. A Black woman was recently elected "Miss $450^{\text {th }}$ Rio de Janeiro's anniversary" (R7, 2015); a contrast to the White, blonde with light-colored eyes, "Miss $4^{\text {th }}$ Centenary". (ARGENTO, 2014). The winner of Miss Brazil 2016 was the second Black woman elected in more than five decades (REVISTA DONNA, 2015). Black women marched in the streets of São Paulo, Rio de Janeiro and Curitiba $(G 1,2016)$ under the slogan Marcha do Orgulho Crespo ("Afro Hair Pride March") using the hair as a symbolic element for the representation of their political activism. Universities have institutionalized spaces such as Núcleos de Estudos Afro-Brasileiros/Center for Afro-Brazilian Studies (NEAB) - for the debate of issues that bring Brazilians closer to their African roots (NEAB UERJ, s.d.). All these examples distance Black female consumers from the inferior status often attributed to them (GRIJÓ; SOUZA, 2012; GRIJÓ, 2014).

Young Black women have become the protagonists of internet videos giving them certain fame and positive reception from the audience. Carolina became known when she clarified that her hair "was not bad, bad is hearing ignorant people say that your hair is 
bad". (MONTEIRO, 2015). Within the area of consumption, the campaign Se Não me Vejo, Não Compro ("If I Don't Recognize Myself, I Don't Buy It") has circulated on the internet portraying kids holding signs with the phrase (RITTER, 2016). The campaign was a response to the decision made by a brand of costumes to represent the character Finn, from Star Wars - performed by Black actor John Boyega - as a White man. Social media gives space for movements that invigorate Blacks in their fight against stigma, invisibility, and prejudice (TELLA, 2006; ZAMORA, 2012).

In public spaces it is possible to observe Black women abandoning hair straightening and returning to their natural hair texture. Moving from one hairstyle to the other represents a period to which they refer as "hair transitioning". Participants of the community Cacheadas em Transição (OFICIAL) deal with this stage as an opportunity for "knowing your hair" and "accepting your roots", "a voluntary experience and the desire for change", pointing to a "learning process about your own self". One member of the community mentions: "I had no idea that I had the right to do whatever I wanted with my hair, even to cut it, if that were the case". Another topic of debates within the community is the "fight and the political activism" implied in abandoning straightening and returning to the natural hair texture. Participants recognize how "difficult" the process is, because "sometimes you get ugly", "sad", and receive "criticism from people".

Among the videos dealing with hair care found on YouTube, we identified videos of young Black women giving tips on how to "transition" without major "trauma" (see GOMES, 2016). The high number of consumers participating in social media communities is noticeable (SIMÕES; SANT'ANNA, 2010), and it serves as a source of support for the stage when the hair has not gained a defined style yet. Cacheadas em Transição (OFICIAL) members mention feeling "encouraged by the Facebook [community]" along the process, also commenting on the gains - "self-esteem, self-confidence and reassurance" - that transitioning in itself may provide.

It seems to be a usual practice among Black women with natural afro-textured hair to "make their own products", as they cannot find good products available in the market. Although interviewees have mentioned some products or brands (products by Beleza Natural salon, the brand "Hair Shine", and the product Morte Súbita among others), "homemade" production seems to have become naturalized. Gaps left by the market made it possible for Black women entrepreneurs to look for solutions that would meet their own needs and others' needs. The salon Beleza Natural, for example, a reference in regard to customer service designed for women with natural afro-textured hair, was born through the initiative of one of its owners who "[...] being a woman that cares for her looks, was unsettled by the lack of products and treatments for hair with natural texture like hers" (SUAREZ; CASOTTI; ALMEIDA, 2008, p. 556).

\section{MARKET OFFERS: SELECTIVE AND VEILED DEMARKETING?}

It was possible to gather Black female consumers' complaints regarding the lack of proper products for their hair within Facebook posts or the interviewees' accounts. Among the participants, Flávia (50 years old), a mother of a teenager, was assertive: "No, I don't find [products] for me, neither for my daughter's [hair]. It's hell". The gap left by the market 
can be fulfilled by the consumers' social network, by the exchange of information and tips concerning the use or not of certain products. This is the case of Amanda (38 years old) whose sister lives in England and "brings loads of [products]" for her.

The current status of the relationship between the market and Black female consumers seems to be somewhat "blurry" concerning hair products offerings. Statistics suggest that many Black Brazilians have gained access to new products and, as a consequence, became more present in various consumption environments (NERI, 2011). This does not seem to have been assimilated by the market of products for natural afro-textured hair. In her account, Cândida (51 years old), for example, deconstructs the recent discourse about a more accessible market when she states that "there are no products for Black women's hair", though she recognizes slight advancements in this direction. According to the interviewee, "they are making products [for Black hair]", albeit her comparison is with "the old days", when "there was nothing; in the past Vaseline was the option" Magda (45 years old), despite showing dissatisfaction and disbelief towards the market for her hair type, points to some developments in terms of product offerings:

When I was a child and an adolescent it was awful [finding good products]. There was only Neutrox [moisturizer cream], creme de mocotó [calf's foot jelly] and, at a certain point, when American products arrived, such as relaxants, the Brazilian industry woke up to the fact that there was a huge space for Black hair products. From the moment those American products got into the market, all of sudden, new releases of Brazilian products started to happen, but by then I was practically leaving Brazil [...] But l've never found one product, till today, that l'd say it's a real good one.

Among the interviewees, even the ones that recognize some improvement in the offers, there is a consensus that "the access to products is not that easy", especially when compared to the market that aims non-Black consumers. Aside from the insufficient offerings, the participants refer to unprepared retailers and salespeople, incapable of providing them a good customer service. Going to a store specialized in hair products may be an unpleasant experience that reminds the consumer of her neglected condition in the marketplace, both in regard to products promotional information and to availability on the shelves. Vanda (44 years old) proposes an explanation for this: "There are companies that have [products], but they are not publicized on TV and don't get attention [referring to a product promotion] because they think that products for Black hair don't sell". Amália (38 years old), on the other hand, ponders that the offer is not compatible with the volume of demand. She said:

It's not easy [to find products] because the ones that target our type of hair sell out quickly [in the stores], because a lot of women you see out there with straight hair, don't have straight hair. She uses a flat iron every day, she blow-dries every day: [the hair] got wet, shrunk, it needs to be treated; and the treatment is with products for afro-textured hair.

The gap left by the market is also recalled when they describe experiences in beauty salons. They talk about the scarcity of services specialized in the treatment of natural afro-textured hair. Establishments do not have professionals properly trained to deal with 
Black hair texture, and this is a significant complaint among interviewees. Vanda, who has "embraced her natural hair texture", talks about the lack of specialized hair salons, despite recognizing that there are hairdressers specialized in specific styles, such as "braids, Nago braids [similar to African box braids] and dreadlocks". The respondent justifies her choice for becoming a hairstylist due to the lack of proper service so that she could "take care of [her] own hair". The "inexistence" of products and services is also part of the history behind Beleza Natural. The chain gained space as a result from the lack of alternatives and offerings of innovative services and products for Black hair texture (SUAREZ et al., 2008). This "non-market" gives space for creativity and to what the marketing literature defines as "prosumer" (see CORDEIRO; CAMPOS, 2015).

Amanda (38 years old), who uses ethnic braids, reinforces the level of informality that Black female consumers experience. Amanda's braids are done by "two hairstylists who are not hairstylists", they are "her friends". These "non-professionals" are praised for their braiding technique skills, an opportunity described by the respondent as "a privilege", "a luxury". Other informal spaces were mentioned by the interviewees, such as a neighbor's home, for example, where "we care for each other's [hair]".

Although they are no longer in operation, two hair salons were mentioned by the interviewees as spaces that promoted Black culture: AfroDai and Afonjá. Those salons were visited by "afro-hair icons" and "pretas da situação" (prominent Black women), celebrities such as actress Zezé Motta, journalist Glória Maria, actor and singer Tony Tornado, politician Benedita da Silva, and actor Antônio Pitanga. Magda (45 years old) suggests an explanation for the recurrent reference to these salons. According to the participant, AfroDai and Afonjá "[...] were the only salons, at the time, having hair care options for Black people, places that offered possibilities of getting a treatment not too far from natural Black traits". Amanda (38 years old) tackles the issue from another perspective: "Afonjá was a rooftop terrace in Copacabana, a salon for the upper class: it was for Blacks, but for the privileged ones". Nowadays the salon Beleza Natural became the reference, more specifically for relaxed hair. Different from AfroDai and Afonjá, Beleza Natural is not associated to the black culture reproduction, but as a space that contributes to the democratization of hair care, albeit promoting one specific hair style-relaxed.

A significant number of salons dedicated to the Black clientele are located in regions far from upscale neighborhoods. According to the interviewees, a woman with straight hair has several options of beauty salons next to her home. A Black woman, on the other hand, depending on her home location, will need to travel long distances and go to another neighborhood if she needs care for her type of hair texture. Claudia (57 years old), for example, lives in an upper-middle class region and finds herself lacking specialized beauty salon options. The participant clarifies that salons targeting Black people are located in poorer areas: "In the periphery, the outskirts, in the north zone". In her attempt to avoid long journeys, Claudia gets her hair treatment in a salon for straight-hair women, close to her home. The result is not always satisfactory, as she says: "Now I go to a salon here, but there's a problem; this girl that does my hair doesn't know, she's not trained; because we don't have professionals here, there are no ethnic hair professionals". Margarida (28 years old) tells that she made several trips to go to a salon along her life. In a narrative excerpt, she lists a number of neighborhoods in the outskirts of Rio de Janeiro, making clear the ordeal Black consumers go through in order to gain access to proper beauty salon services: 
Then I moved to Penha; it was more distant [from the salon]. It would take me 1 hour or 1 hour and a half to get there, but it was a real salon. I remained a customer there for 1 year, doing afro perm. Then I stopped going there and ended up in Água Santa, next to Méier. I went to Praça Seca. Then I quit Praça Seca and went to Duque de Caxias. Duque de Caxias is close to my home, it's not far; I used to get there in 30 to 40 minutes.

Aside from the time spent in trips to beauty salons that offer Black hair care, some interviewees remember the long hours needed to get their hair treatment. Magda generalizes: "When a Black person goes to the hairdresser, she doesn't spend 1 hour, she spends an entire day at the salon".

The interviews' narratives and the data collected from the internet point to several difficulties related to the experience with Black female consumers' hair beauty products, services and treatment of. Women also talk about actions and practices they promote and reinforce within their kinship network, such as friends and neighbors, and also through social network online sharing, collaboration and support. Where is the market? In relation to the consumption of services and goods for Black hair, according to the testimonial accounts and internet posts, the market seems timid and discouraging. Would this be selective demarketing? At a certain point during her interview, Heloisa (31 years old) reveals feeling invisible by a market that "pretends" to meet her demands. Would it be selective and veiled demarketing?

What I feel sometimes is that there are creams that don't moisturize a damn thing. [My hair] feels more like straw. Was the [the product] tested on someone? Who was is it made for? Who was the model for the development of this moisturizer? I can't see the result in my hair or my friends' hair.

\section{FINAL DISCUSSION}

Black women learn that the existing beauty standard differs from their natural traits. Their stories describe a market that offers products and services that intend to change their genuine aesthetics, instead of keeping or recovering them. Straightened hair is "practical" (NDICHU; UPADHYAYA, 2018), but render their natural physical attributes invisible. Straightened hair approximate Black women to White aesthetics and might diminish the stigma related to their natural hair texture (kinky, coiled or curly). Representations and market practices may have led Black women in a direction opposite to that of identity building which is something closely related to consumption (BELK, 1988; SLATER, 1997; WARDE, 1994) i.e. market actions, in this case, seem to disrupt or even deconstruct the identity of this group of women. Firat and Venkatesh (1995) explain the phenomenon as the development of an "empty self" or a "decentralized self".

Despite pertaining to distinct socio-historical contexts, our findings have a parallel with the research by Ndichu and Upadhyaya (2018) on the trajectory of identity change followed by Kenyan Black women, which happened through the adoption of natural hair texture. Within our primary and secondary data we also identified movements promoting the embracement of natural hair, for example Marcha do Orgulho Crespo and the Facebook 
group Cacheadas em Transição. These new movements seeking identity construction should instigate Brazilian companies to see the "invisible". Marketing actions, however, are predominantly directed to the non-Black population, and seem to demotivate the participation of Black people in the marketplace. The interviewees reported feeling discouraged and recounted their search for alternatives to fill in the gaps left by the market.

The concept of selective demarketing encourages reflections regarding the business side. Companies that in fact want to control the demand or, in other words, discourage the consumption by Black women, may find in this group an "easy target". Racism has been historically denied in Brazil. It is not possible to assert that neglecting situations those consumers face in the marketplace result from a voluntary selective demarketing, although the accounts do point to the existence of selective demarketing, even if veiled.

Going back to Kotler's (1973) seminal article on demarketing, in which the author places it among marketing managerial tasks, our findings point to a paradox. The narratives suggest the existence of a latent demand, i.e., Black women need products and services that are not properly offered by the market. Kotler reminds us that latent demand is a sign of a favorable environment for innovation within companies, though the examined experiences seem distant from actions aiming at demand development ("developmental marketing"). The author gives hints to elucidate the paradox posed by our research findings, when "latent demand" is interpreted as selective demarketing. Kotler (1973, p. 47) correlates this kind of demarketing to situations when organizations are not willing to reduce overall demand, but are instead focusing on certain relevant market segments.

Kotler's article does not cover socioeconomic or racial issues when referring to "non-profitable" or "undesirable" market needs. Nevertheless, market segmentation strategies in Brazil seem to obscure the importance of Black people as consumers, while reinforcing the hegemony of the non-Black population (LENGLER et al. 2002). Meanwhile, new movements, mainly developed within digital platforms, instigate the Brazilian market to see the "invisible" and the "undesirable".

This study contributes to stimulate Brazilian companies' reflection upon racial issues that influence the market and marketing actions. "The consumer has no color, but they are not Black". The content of such expression, coined decades ago, seems to remain present in the imaginary and in business practices. It reveals the veiled racism. Racism is a crime in Brazil. Yet, on a daily basis, veiled racism exists in discourses and representations suggesting that social acceptance of Black people is not real, but a pretense. Brazil is not a racial democracy as many Brazilians wish to think or have been led to believe and disseminate. In practice, this belief makes the debates on existing racism within the marketplace even more difficult, precisely where a number of topics need to be explored in order to challenge knowledge that has been developed in the theories and practices by predominantly White researchers.

\section{REFERENCES}

A NEGAÇÃO DO BRASIL: o negro na telenovela brasileira. Direção de Joel Zito Araújo. Produção de Joel Zito Araújo. Rio de Janeiro: Casa de Criação, 2000. Available on: <https:// vimeo.com/190642004>. Acessed on aug 28, 2017. 
ABIHPEC - Associação Brasileira da Indústria de Higiene Pessoal, Perfumaria e Cosméticos Panorama do setor de higiene pessoal, perfumaria e cosméticos. 2015. Available on: $<$ https://www.abihpec.org.br/novo/wp-content/uploads/PANOMARA-DO-SETOR-2016.pdf>. Acessed on aug 28, 2017.

APPIAH, K. A. Na casa de meu pai: a África na filosofia da cultura. Rio de Janeiro: Contraponto, 1997.

ARAÚJO, J. Z. A Negação do Brasil: o negro na telenovela brasileira. São Paulo: Senac, 2000. p. 22-75.

- O negro na dramaturgia, um caso exemplar da decadência do mito da democracia racial brasileira. Revista Estudos Feministas, v. 16, n. 3, p. 979-985, 2008.

ARGENTO, B. Uma rainha para os 450 anos do Rio. 2014. Available on: <http://blogs. odia.ig.com.br/rio-450-anos/historias-do-rio/uma-rainha-para-os-450-anos-do-rio $>$. Acessed on jul 28, 2017.

ARNOULD, E. J.; THOMPSON, C. J. Consumer culture theory (CCT): Twenty years of research. Journal of Consumer Research, v. 31, n. 4, p. 868-882, 2005.

ARVIDSSON, A. Brands: a critical perspective. Journal of Consumer Culture, v. 5, n. 2, p. 235-258, 2005.

BARBOSA, L. Sociedade de consumo. Rio de Janeiro: Jorge Zahar, 2004.

BARDIN, L. Análise de conteúdo. Lisboa: Edições 70, 2006.

BAUER, R. A.; CUNNINGHAM, S. M.; WORTZEL, L. H. The Marketing Dilemma of Negroes. Journal of Marketing, v. 29, p. 1-6, jul. 1965.

BEETON, S. Swimming against the tide - integrating marketing with environmental management via demarketing [online]. In: BRAITHWAITE, R. L.; BRAITHWAITE, R. W. (ed.). CAUTHE 2003: Riding the Wave of Tourism and Hospitality Research. Lismore, N.S.W.: Southern Cross University, 2003, p. 107-121.

BELK, R. W. Possessions and the extended self. Journal of Consumer Research, v. 15, n. 2, p. 139-168, 1988.

BELK, R. W.; GER, G.; ASKEGAARD, S. The fire of desire: A multisited inquiry into consumer passion. Journal of Consumer Research, v. 30, n. 3, p. 326-351, 2003.

BENNETT, A. et al. Shopping While Nonwhite: Racial Discrimination in The Marketplace. Advances in Consumer Research, v. 42, 2014.

BOUZÓN, P. G. Cabelos e construção de identidades: incursão antropológica em um salão de beleza carioca. In: CASOTTI, L.; SUAREZ, M.; CAMPOS, R. D. (orgs.). 0 tempo da Beleza: consumo e comportamento feminino, novos olhares. Rio de Janeiro: Senac Nacional, 2008. $272 p$.

BULLOCK, H. A. Consumer motivations in black and white. Harvard Business Review, v. 39, n. 89, p. 16, 1961.

BREAKWELL, G. M. Coping with Threatened Identities. London: Methuen, 1986. 
CARNEIRO, S. Expectativas de ação das empresas para superar a discriminação racial. Reflexão, ano 3, n. 8, 2002.

CORDEIRO, C. A.; CAMPOS, R. D. De Prossumidoras a produtoras: A trajetória das donas de salão de beleza da Rocinha. Revista Economia \& Gestão, v. 15, n. 40, p. 28-56, 2015.

CROCKER, J.; MAJOR, B.; STEELE, C. Social stigma. In: LINDZEY, G.; FISKE, S. T. (eds.). The handbook of social psychology. New Jersey: Lawrence Erlbaum, 1998, p. 504-553.

CULLWICK, D. Positioning demarketing strategy. Journal of Marketing, p. 51-57, v. 39, n. 2, 1975.

DA MATTA, R. 0 que faz o brasil, Brasil? Rio de Janeiro: Rocco, 1986.

DOMINGUES, P. J. Negros de almas brancas? A ideologia do branqueamento no interior da comunidade negra em São Paulo. Estudos Afro-asiáticos, v. 24, n. 3, 2002.

FIRAT, F.; VENKATESH, A. Liberatory postmodernism and the re- enchantment of consumption. Journal of Consumer Research, v. 22, p. 239-67, 1995.

FORDHAM, S. Blacked out: dilemmas of race, identity, and success at Capital High. Chicago: University of Chicago Press, 1996.

FREYRE, G. Casa-grande e senzala. Berkeley, CA: Universitv of California Press, 1986.

G1. Atriz Taís Araújo é alvo de comentários racistas em rede social. 2015. Available on: <http://g1.globo.com/rio-de-janeiro/noticia/2015/11/atriz-tais-araujo-e-alvo-de-comentarios-racistas-em-rede-social.html>. Acessed on jul 28, 2017.

$1^{\text {a }}$ marcha do orgulho crespo reúne 500 pessoas em Curitiba. 2016. Available on: <http://g1.globo.com/pr/parana/noticia/2016/11/1-marcha-do-orgulho-crespo-reune-500-pessoas-em-curitiba.html>. Acessed on jul 30, 2017.

GEMAA. Infográfico: A Raça e o Gênero nas Novelas dos Últimos 20 Anos. [2015?] Available on: <http://gemaa.iesp.uerj.br/publicacoes/infografico/infografico3.html>. Acessed on aug 28, 2017.

GERSTNER, E.; HESS, J.; CHU, W. Demarketing as a differentiation strategy. Marketing Letters, v. 4, n. 1, p. 49-57, 1993.

GIDDENS, A. Modernity and self-identity: self and society in the late modern age. Stanford university press, 1991.

GOFFMAN, E. Stigma: Notes on the Management of Spoiled Identity. Englewood Cliffs, NJ: Prentice Hall, 1963.

GOMES, N. L. Educação, identidade negra e formação de professores/as. Revista Educação e Pesquisa, v. 29, n. 1, p. 167-182, 2003.

GOMES, J. 5 formas de passar pela transição que deram super certo. 2016. Available on: <https://www.youtube.com/watch?v=po7K4gYxonQ>. Acessed on jul 30, 2017.

GRINSTEIN, A.; NISAN, U. Demarketing, minorities, and national attachment. Journal of Marketing, v. 73, n. 2, p. 105-122, 2009. 
GRIJÓ, W. P. Narrativa Seriada e Questões Étnico-Raciais: Telenovela como Recurso Comunicativo de Visibilidade da Etnicidade Negra. Ação midiática: estudos em comunicação, sociedade e cultura, v. 7, p. 1-15, 2014.

GRIJÓ, W. P.; SOUSA, A. H. F. O negro na telenovela brasileira: a atualidade das representações. Estudos em Comunicação, n. 11, p. 185-204, 2012.

GROFF, C. Demarketing in park and recreation management. Managing Leisure, v. 3, n. 3, p. 128-135, 1998.

GROSS, D. Raça Identificada: a quebra da invisibilidade negra. Parágrafo: Revista Científica de Comunicação Social da FIAM-FAAM, v. 2, n. 2, p. 212-227, 2014.

GUNDLACH, G. T.; BRADFORD, K. D.; WILKIE, W. L. Countermarketing and Demarketing against product diversion: forensic research in the firearms industry. Journal of Public Policy \& Marketing, v. 29, n. 1, p. 103-122, 2010.

HALL, S. 'What is This 'Black'in Black Popular Culture?' Social Justice, v. 20, n. 1-2, p. 104-14, 1993.

HARRISON III, R. L.; THOMAS, K. D.; CROSS, S. N. Negotiating cultural ambiguity: the role of markets and consumption in multiracial identity development. Consumption Markets \& Culture, v. 18, n. 4, p. 301-332, 2015.

HOLT, D. Why do brands cause trouble? A dialectical theory of consumer culture and branding. Journal of Consumer Research, v. 29, n. 1, p. 70-90, 2002.

HOLT, D. B.; THOMPSON, C. J. Man-of-action heroes: The pursuit of heroic masculinity in everyday consumption. Journal of Consumer research, v. 31, n. 2, p. 425-440, 2004.

IBGE - Instituto Brasileiro de Geografia e Estatística. Síntese de Indicadores Sociais: Uma análise das condições de vida da população brasileira 2014. Available on: < http://ftp.ibge. gov.br/Indicadores_Sociais/Sintese_de_Indicadores_Sociais_2014/SIS_2014.pdf >. Acessed on jul 28, 2017.

IPEA - Instituto de Pesquisa Econômica Aplicada. Igualdade Social no Brasil: Reflexões no Ano Internacional dos Afrodescendentes. 2013. Available on: <http://www.portaldaigualdade. gov.br/central-de-conteudos/publicacoes/pub-acoes-afirmativas/livro_igualdade_racialbrasil01-tamanho-reduzido.pdf>. Acessed on jul 06, 2015.

KARYY, O.; TRACH, O. Demarketing of fuel and energy resources in housing and utilities sector. SLOG, v. 789, 2014.

KOTLER, P. The major tasks of marketing management. Journal of Marketing, v. 37, p. 42-49, 1973.

KOTLER, P.; LEVY, S. J. Demarketing, yes, demarketing. Harvard Business Review, v. 49, n. 6, p. 74, 1971.

KOTLER, P. Reinventing marketing to manage the environmental imperative. Journal of Marketing, v. 75, n. 4, p. 132-135, 2011.

KOZINETS, R. Can consumers escape the market? Emancipatory illuminations from burning man. Journal of Consumer Research, v. 29, p. 20-38, 2002. 
LAMONT, M.; MOLNÁR, V. How blacks use consumption to shape their collective identity evidence from marketing specialists. Journal of Consumer Culture, v. 1, n. 1, p. 31-45, 2001.

LEE, D.; CUTLER, B. D.; BURNS, J. The marketing and demarketing of tobacco products to low-income African-Americans. Health marketing quarterly, v. 22, n. 2, p. 51-68, 2005.

LEITÃO, M. História do futuro: o horizonte do Brasil no século XXI. 1. ed. Rio de Janeiro: Intrínsica, 2015. 480 p.

LENGLER, J. F. B.; VIEIRA, M. M. F.; FACHIN, R. C. Um exercício de desconstrução do conceito e da prática de segmentação de mercado inspirado em Woody Allen. Revista de Administração de Empresas, v. 42, n. 4, p. 1-9, 2002.

LINK, B. G.; PHELAN, J. C. Conceptualizing stigma. Annual review of Sociology, n. 27, p. 363-385, 2001.

LUNT, P. K.; LIVINGSTONE, S. Mass consumption and personal identity: Everyday economic experience. Open University Press, 1992.

MARK, A.; BRENNAN, R. Demarketing: managing demand in the UK National Health Service. Public Money \& Management, v. 15, n. 3, p. 17-22, 1995.

MARTINS, C. A. M. E. O mercado consumidor brasileiro e o negro na publicidade. GV-executivo, v. 14, n. 1, p. 43-45, 2015.

MCCRACKEN, G. D. Big hair: A journey into the transformation of self. Viking, 1995.

MCGRATH, M. T. Demarketing public lands recreation to protect wilderness resource values. 104 f. Dissertation, California State University, Northridge. 2008.

MIKLOS-THAL, J.; ZHANG, J. (De)marketing to manage consumer quality inferences. Journal of Marketing Research, v. 50, n. 1, p. 55-69, 2013.

MILES, M. B.; HUBERMAN, A. M.; SALDANA, J. Qualitative data analysis. London: Sage, 2013.

MIRANDA-RIBEIRO, P. Somos racistas. Revista Brasileira de Estudos de População, v. 23, n. 2, p. 375-377, 2006.

MONTEIRO, C. Cabelo duro? Carolina afirma que não. 2015. Available on: <https://www. youtube.com/watch?v=d1d0JxGTGOg > . Acessed on jul 30, 2017.

NEAB/UERJ. Núcleo de Estudos Afro-brasileiros. Início. Available on: <http://www.neab. uerj.br/>. Acessed on aug 28, 2017.

NERI, M. C. A Nova Classe Média: o lado brilhante da base da pirâmide. São Paulo: Editora Saraiva, 2011.

NDICHU, E. G.; UPADHYAYA, S. "Going natural": Black women's identity project shifts in hair care practices. Consumption Markets \& Culture, p. 1-24, 2018.

OLIVEIRA, J. S. Representações das relações entre cultura, consumo e etnia: as representações culturais das mulheres negras no mercado consumidor brasileiro. Revista de Administração da UNIMEP, v. 9, n.2, p. 87-107, 2011. 
OLIVEIRA, J. S.; VIEIRA, F. G. D. Os bens de consumo como mecanismo de mediação da reprodução cultural das mulheres negras. Comunicação, Mídia e Consumo, v. 6, n. 17, p. 73- 99, 2009.

PEDROSA, A.; SCHWARCZ, L. M. Antologia de textos Histórias Mestiças. 1. ed. Rio de Janeiro/RJ: Cobogó, 2014.

PIRES, K. T.; MOCELLIN, M. C. Manipulando cabelos e identidades: um estudo com mulheres negras em Santa Maria-RS. Revista África e Africanidades, n. 21, jan-abr. 2016.

R7. Musa da Rocinha é eleita rainha Rio 450 anos. 2015. Available on: <http:// noticias.r7.com/rio-de-janeiro/fotos/musa-da-rocinha-e-eleita-rainha-rio-450-anos18012015?utm_source $=$ WhatVDigital\&utm_medium $=$ banner\&utm_content $=$ Tecnologia\&utm_campaign $=$ noticiasutm_source $=$ WhatVDigital\&utm_medium $=$ banner\&utm_content=Tecnologia\&utm_campaign=noticias\#!/foto/1 > . Acessed on jul 28, 2017.

RAMOS, L. Na minha pele. Rio de Janeiro: Objetiva, 2017.

REMENYI, D. et al. Doing research in business and management: an introduction to process and method. Thousand Oaks, CA: Sage, 1998.

REVISTA DONNA. Miss Brasil 2016: representante do Paraná é a segunda negra a vencer o concurso. 2016. Available on: <http://revistadonna.clicrbs.com.br/gente/miss-brasil-2016-representante-do-parana-e-segunda-negra-vencer-o-concurso/> . Acessed on jul 28, 2017.

RIBEIRO, D. Ser atrevida? Só se for pra agradar homem. 2015. Available on: <https:// www.cartacapital.com.br/sociedade/ser-atrevida-so-se-for-pra-agradar-homem-5074. html>. Acessed on jul 30, 2017.

RIBEIRO, S. Eu não perdoo a Fernanda Torres. 2016. Available on: <http://www.huffpostbrasil.com/stephanie-ribeiro/eu-nao-perdoo-a-fernanda-torres_a_21684549/>. Acessed on jul 28, 2017.

RITTER, D. Depois de boneco do Star Wars, crianças negras fazem campanha: "Não me vejo, não compro". 2016. Available on: <http://revistadonna.clicrbs.com.br/comportamento-2/ nao-vejo-nao-compro-criancas-negras-participam-de-campanha-sobre-falta-de-representatividade/>. Acessed on jul 30, 2017.

ROCHA, A. R.; CASOTTI, L. Reflexões sobre o consumidor negro brasileiro. Revista Pensamento Contemporâneo em Administração, v. 11, n. 2, p. 47-62, 2017.

ROCHA, A. R.; SCHOTT, C.; CASOTTI, L. Socialization of the Black Female Consumer: Power and Discourses in Hair-Related Consumption. NA - Advances in Consumer Research, v. 44, 2016.

SANDIKCI, Ö.; GER, G. Veiling in style: how does a stigmatized practice become fashionable? Journal of Consumer Research, v. 37, n. 1, p. 15-36, 2009.

SIMÕES, R. C.; SANT'ANNA, S. R. A beleza dos cabelos crespos e cacheados: um olhar a partir de uma comunidade virtual do orkut. In: ENCONTRO DA ANPAD, 34., Rio de Janeiro, 2010. Anais... Anpad: Rio de Janeiro, 2010.

SLATER, D. Consumer culture and modernity. Cambridge: Polity Press, 1997. 
SUAREZ, M. C.; CASOTTI, L. M.; ALMEIDA, V. M. C. Beleza Natural: crescendo na base da pirâmide. RAC: revista de administração contemporânea, v. 12, p. 22-30, 2008.

TELLA, M. A. P. Reação ao estigma: o rap em São Paulo. Revista Enfoques, v. 5, n. 1, 2006.

THOMPSON, C. Black women and identity: What's hair got to do with it. Michigan Feminist Studies, v. 22, n. 1, 2009.

TODA, F. A. Um estudo sobre clientes indesejados em empresas de pequeno porte. In: ENCONTRO DE ESTUDOS SOBRE EMPREENDEDORISMO E GESTÃO DE PEQUENAS EMPRESAS, 9., Passo Fundo, RS, 2016. Anais... Passo Fundo, RS: Egepe, 2016.

TOMÁS, J. C. S. P. A invisibilidade social: uma análise hermenêutica. In: CONGRESSO INTERNACIONAL COMUNICAÇÃO, COGNIÇÃO E MIDIA (CICOM). Portugal, Braga, 2009. Anais... CICOM, Portugal, 2009, p. 1507-1516.

TOMLINSON, A. Consumption, identity and style: marketing, meanings, and the packaging of pleasure. London: Routledge, 2006.

VASCOUTO, L. 8 estereótipos racistas que novelas brasileiras precisam parar de usar. Nó de oito. 2016. Available on: <http://nodeoito.com/estereotipos-racistas-novelas-brasileiras/>. Acessed on aug 28, 2017.

WARDE, A. Consumers, identity and belonging: Reflections on some theses of Zygmunt Bauman. In: KEAT, R.; WHITELEY, N.; ABERCROMBIE, N. (eds.). The Authority of the Consumer. London: Routledge, 1994. p.58-74.

WHITE, C. J.; THOMAS, H. Up in smoke: demarketing and consumer smoking cessation. International Journal of Consumer Studies, v. 40, n. 1, p. 75-82, 2016.

ZAMORA, M. H. R. N. Desigualdade racial, racismo e seus efeitos. Fractal: Revista de Psicologia, v. 24, n. 3, p. 563-578, 2012.

Data de submissão: 20/09/2017.

Data de aprovação: 24/07/2018.

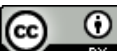

Creative Commons Atribuição 4.0 Internacional

Note: you can find this paper in Portuguese at http://www.revistaoes.ufba.br. 